\title{
Predeployed aortic extension cuff (kilt) in EVAR with hostile neck anatomy using Endurant II system: preliminary results
}

\author{
Krzysztof Szaniewski ${ }^{1}$, Magdalena Biernacka ${ }^{1}$, Ryszard L Walas ${ }^{2}$, Marian Zembala² \\ ${ }^{1}$ St. Barbara Provincial Specialist Hospital No. 5, Sosnowiec, Poland \\ ${ }^{2}$ Department of Cardiac, Vascular and Endovascular Surgery and Transplantology, Silesian Centre for Heart Disease, SMDZ \\ in Zabrze, Medical University of Silesia in Katowice, Poland
}

Kardiochirurgia i Torakochirurgia Polska 2016; 13 (4): 334-339

\begin{abstract}
Introduction: Various modifications of standard endovascular aortic aneurysm repair (EVAR) have been developed to solve the problem of difficult neck anatomy.

Aim: The authors propose the implantation of a predeployed extension cuff (kilt) using on-shelf Endurant II elements. In a vast majority of cases, the proposed method provides a solution for the hostile neck problem using standard Endurant II elements available in all centers performing subrenal EVAR procedures.

Material and methods: The early outcomes of kilt implantation were evaluated in 11 patients (three with ruptured abdominal aortic aneurysms, one symptomatic) in 2 vascular centers in Silesia (Poland). All patients presented with hostile neck anatomy defined as neck length $<10 \mathrm{~mm}$, diameter $>28 \mathrm{~mm}$, angulation $>60^{\circ}$, mural thrombus or calcium $>2 \mathrm{~mm}$ in thickness or $>180^{\circ}$ circumference.

Results: No intraoperative type I endoleak or device migration was observed. Two perioperative deaths occurred in patients in a severe condition with ruptured aneurysms. One case of type III endoleak was managed by the implantation of an additional iliac extension with complete endoleak sealing. Conclusions: The proposed method seems to be effective in early endoleak prevention in patients with hostile neck anatomy undergoing EVAR procedures; however, studies with longterm follow-up are needed.
\end{abstract}

Key words: abdominal aortic aneurysm, hostile neck, endoleak, kilt technique.

\section{Introduction}

The morphological features of the aortic neck are crucial factors in technical and clinical success of endovascular aortic aneurysm repair (EVAR). The most frequent criteria

\section{Streszczenie}

Wstęp: Opracowano różne modyfikacje standardowego zabiegu wewnątrznaczyniowej naprawy tętniaka (EVAR) w celu rozwiązania problemu trudnej anatomii szyi tętniaka.

Cel: Autorzy proponują preimplantację mankietu przedłużającego (kiltu) z zastosowaniem szeroko dostępnych elementów systemu Endurant II. W większości przypadków proponowana metoda umożliwia rozwiązanie problemu trudnej anatomii szyi tętniaka przy użyciu standardowych elementów systemu Endurant II, będących na wyposażeniu wszystkich ośrodków przeprowadzających zabiegi EVAR w odcinku podnerkowym.

Materiat i metody: Oceniono wczesne wyniki implantacji kiltu u 11 pacjentów (u 3 z pękniętymi tętniakami aorty brzusznej, u 1 z tętniakami objawowymi) w dwóch śląskich ośrodkach naczyniowych. U wszystkich pacjentów stwierdzono trudną anatomię szyi tętniaka zdefiniowaną jako: długość szyi < $10 \mathrm{~mm}$, średnica $>28 \mathrm{~mm}$, zagięcie $>60^{\circ}$, przyścienna skrzeplina lub zwapnienie $>2 \mathrm{~mm}$ grubości lub $>180^{\circ}$ obwodu.

Wyniki: U żadnego z pacjentów nie zaobserwowano przecieku wewnętrznego typu I ani przemieszczenia się protezy. Dwóch pacjentów w ciężkim stanie, z pękniętymi tętniakami zmarło w okresie okołooperacyjnym. W jednym przypadku, w którym doszło do przecieku wewnętrznego typu III, dokonano implantacji dodatkowego przedłużenia biodrowego z całkowitym zamknięciem przecieku.

Wnioski: Proponowana metoda wydaje się skuteczna w zapobieganiu wczesnym przeciekom wewnętrznym przy zabiegach EVAR w przypadku trudnej anatomii szyi tętniaka; niemniej potwierdzenie skuteczności metody wymaga obserwacji długoterminowej.

Słowa kluczowe: tętniak aorty brzusznej, trudna szyja, przeciek wewnętrzny (endoleak), kilt.

that exclude patients from successful graft deployment are: pararenal aneurysm and severe angulations at the level of celiac and renal arteries. These issues can be managed by open or endovascular repair. Open surgical aneurysm re-

Address for correspondence: Krzysztof Szaniewski MD, PhD, St. Barbara Provincial Specjalist Hospital No. 5, Plac Medyków 1, 41-200 Sosnowiec, Poland, phone: +48 3236825 81, e-mail: kszaniewski@gmail.com

Received: 26.10.2016, accepted: 24.11.2016. 
Tab. I. Patient's demographics and risk factors

\begin{tabular}{|c|c|c|c|c|c|c|c|c|}
\hline Age & Gender & ASA & $\begin{array}{l}\text { Arterial hy- } \\
\text { pertension }\end{array}$ & $\begin{array}{l}\text { Ischemic heart } \\
\text { disease (CCSIII) }\end{array}$ & $\begin{array}{c}\text { Myocardial } \\
\text { infarction history }\end{array}$ & Diabetes & $\begin{array}{l}\text { Chronic renal } \\
\text { insufficiency }\end{array}$ & Other \\
\hline 73 & M & Ve & Y & Y & Y & $\mathrm{N}$ & N & Hypovolemic shock \\
\hline 74 & $M$ & III & $Y$ & $Y$ & $\mathrm{Y}$ & $\mathrm{N}$ & N & \\
\hline 69 & M & III & Y & Y & Y & Y & $\mathrm{N}$ & \\
\hline 64 & $\mathrm{~F}$ & IV & $Y$ & $Y$ & $\mathrm{~N}$ & $\mathrm{~N}$ & $\mathrm{~N}$ & \\
\hline 81 & $\mathrm{~F}$ & IV & $Y$ & $Y$ & $\mathrm{~N}$ & $\mathrm{~N}$ & $\mathrm{Y}$ & \\
\hline 77 & M & III & $\mathrm{Y}$ & $Y$ & $\mathrm{~N}$ & $\mathrm{~N}$ & N & \\
\hline 69 & $M$ & III & $Y$ & $\mathrm{~N}$ & $\mathrm{~N}$ & $\mathrm{~N}$ & $\mathrm{~N}$ & Pulmonectomy (Ca) \\
\hline 67 & $M$ & III e & $\mathrm{Y}$ & $N$ & $\mathrm{~N}$ & $\mathrm{Y}$ & $\mathrm{N}$ & Symptomatic AAA \\
\hline 63 & $\mathrm{~F}$ & III & $Y$ & $\mathrm{Y}$ & $\mathrm{Y}$ & $\mathrm{N}$ & $\mathrm{N}$ & \\
\hline 73 & $\mathrm{~F}$ & $\mathrm{Ve}$ & $Y$ & $Y$ & $Y$ & $\mathrm{Y}$ & $\mathrm{N}$ & Hypovolemic shock \\
\hline 63 & $\mathrm{~F}$ & $\mathrm{Ve}$ & $\mathrm{Y}$ & $\mathrm{N}$ & $\mathrm{N}$ & $Y$ & $\mathrm{Y}$ & Hypovolemic shock \\
\hline
\end{tabular}

e-emergency procedure.

pair (OR) still remains the gold standard in vascular surgery, despite limitations resulting from high perioperative risk. The OR approach with the necessity of aortic clamping and renal/celiac artery reimplantation has limited availability for patients with severe comorbidities, very common in abdominal aortic aneurysm (AAA) patients. Its outcome may be complicated by abdominal organ ischemia, neurological deficits and problems arising from surgical access (laparotomy an thoracotomy simultaneously).

For such patients a second choice is a fenestrated graft (fEVAR), which allows treatment of aneurysms that encapsulate celiac and renal arteries' origin by a minimally invasive method. Unfortunately, the availability of the fEVAR procedure is limited to high-volume clinical centers due to high cost of the procedure and its technical complexity. Another disadvantage of fEVAR is the fact that the procedure cannot be applied to patients with symptomatic and/or ruptured aneurysms.

However, for a substantial group of patients it is possible to use a standard on-shelf EVAR device with some modifications and adjuncts.

We introduce an alternative approach using the Endurant II device, where an infrarenal aortic covered cuff is predeployed into an AAA hostile neck. The main graft body is then implanted to a "channel" made by a previously deployed aortic extension. Such a strategy makes it possible to avoid an open repair or fenestrated graft implantation, while the treatment goals are met.

\section{Aim}

The authors propose the implantation of a predeployed extension cuff (kilt) using on-shelf Endurant II elements. In a vast majority of cases, the proposed method provides a solution for the hostile neck problem using standard Endurant II elements available in all centers performing subrenal EVAR procedures.

\section{Material and methods}

During the EVAR qualification procedure between June 2015 and May 2016 we identified 11 patients (including 1 case of symptomatic AAA and 3 cases of ruptured AAA) with hostile neck anatomy that was unfit for open repair, due to high perioperative risk. All patients ( 5 female, 6 male) were classified in the ASA III-V group according to various comorbidities or a severe general condition. Ten procedures were performed with local anesthesia with analgo-sedation and one in general anesthesia.

Patients' demographics and risk factors are presented in Table I.

The term hostile neck anatomy (HNA) was initially used in 2003 by Dillavou et al. [1]. In the literature different definitions of HNA exist. In general, several anatomical factors are taken into account when defining a hostile neck patient: neck length (usually $<15 \mathrm{~mm}$ ), diameter (> $28 \mathrm{~mm}$ ) and angulation $\left(>60^{\circ}\right)$. Other adverse morphological parameters include proximal neck circumferential thrombus or calcification (>50\%) or a tapered/conical neck, wherein the diameter progressively increases between the renal arteries and the sac with a $>2$ - to $3-\mathrm{mm}$ change over the first $15 \mathrm{~mm}$ of the proximal neck [2-6].

In our study all 11 patients met the criteria of hostile neck defined in the study of Jordan et al. [6]: neck length $<10 \mathrm{~mm}$, diameter $>28 \mathrm{~mm}$, angulation $>60^{\circ}$, mural thrombus or calcium $>2 \mathrm{~mm}$ in thickness or $>180^{\circ}$ of circumference.

In 4 patients, short and conical neck was the main reason for cuff predeployment (Fig. 1). In 7 of 11 cases, the extension cuff was predeployed because of severe angulation of the proximal landing zone (Fig. 2).

In all cases additional pathologies of the arterial morphology existed as iliac tortuosity, landing zone thrombus or calcifications (Tab. II).

Anatomical information regarding challenging aortic neck was acquired from contrast enhanced computed 

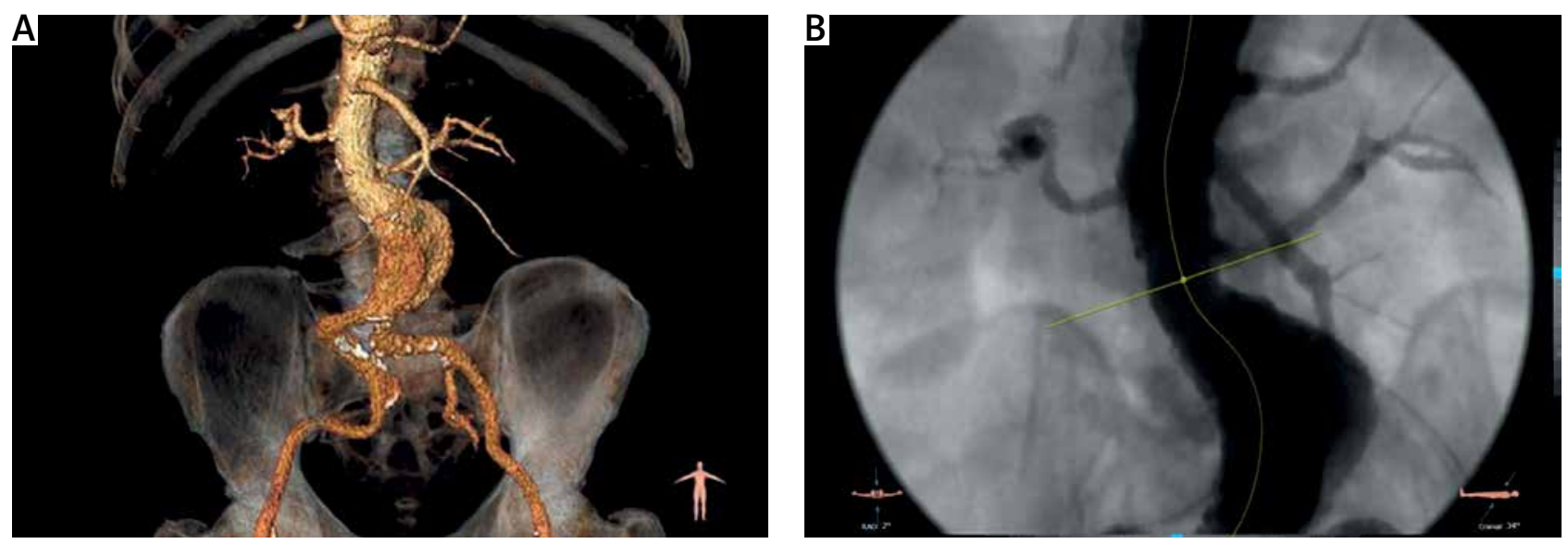

Fig. 1. A, B - Example of short and conical neck
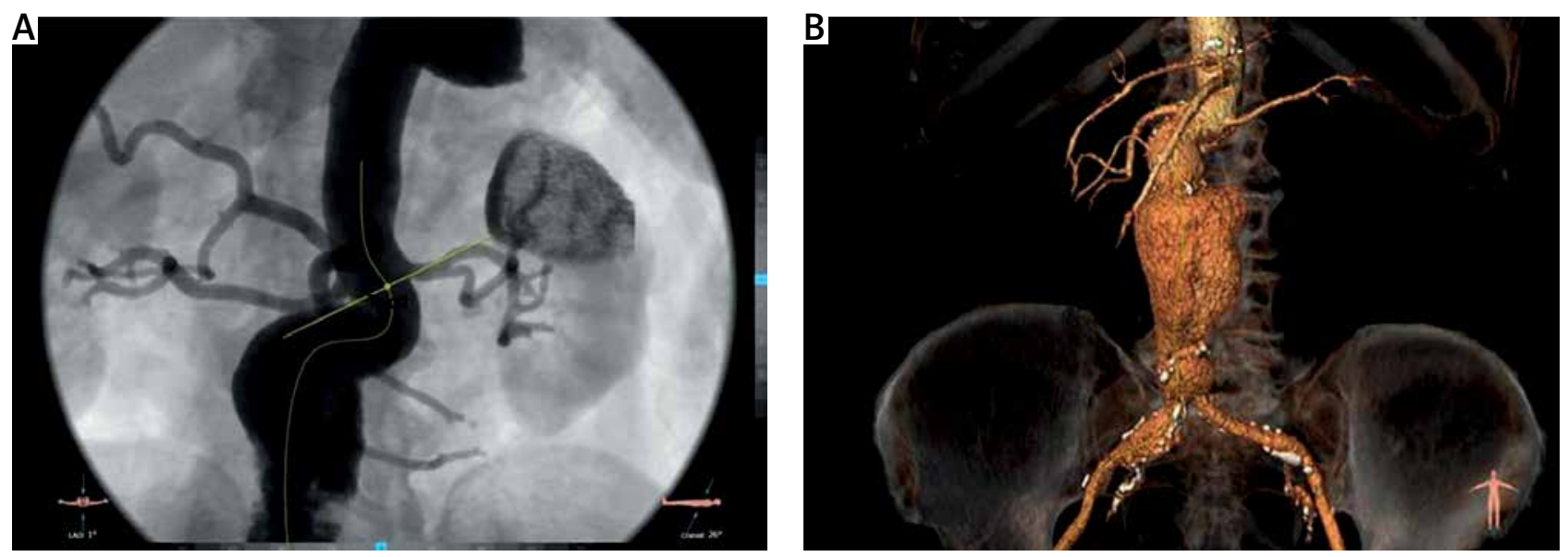

Fig. 2. A, B - Example of severe angulation

Tab. II. Aneurysm morphology and clinical features

\begin{tabular}{cccccccc}
$\begin{array}{c}\text { Rup- } \\
\text { ture }\end{array}$ & $\begin{array}{c}\text { AAA } \\
\text { diameter } \\
{[\mathrm{mm}]}\end{array}$ & $\begin{array}{c}\text { Neck Conical Neck } \\
\text { length }\end{array}$ & $\begin{array}{c}\text { Neck } \\
\text { neck }\end{array}$ & $\begin{array}{c}\text { Infra- } \\
\text { throm- } \\
\text { bus } \\
\text { renal } \\
\text { angle }\left[{ }^{\circ}\right]\end{array}$ & $\begin{array}{c}\text { Supra- } \\
\text { renal } \\
\text { angle }\left[{ }^{\circ}\right]\end{array}$ \\
\hline $\mathrm{N}$ & 84 & 8 & $\mathrm{Y}$ & $\mathrm{Y}$ & $\mathrm{Y}$ & 53 & 44 \\
\hline $\mathrm{N}$ & 100 & 15 & $\mathrm{~N}$ & $\mathrm{Y}$ & $\mathrm{N}$ & 95 & 75 \\
\hline $\mathrm{N}$ & 51 & 15 & $\mathrm{~N}$ & $\mathrm{~N}$ & $\mathrm{~N}$ & 100 & 95 \\
\hline $\mathrm{N}$ & 70 & 12 & $\mathrm{~N}$ & $\mathrm{~N}$ & $\mathrm{~N}$ & 110 & 80 \\
\hline $\mathrm{N}$ & 55 & 12 & $\mathrm{~N}$ & $\mathrm{Y}$ & $\mathrm{Y}$ & 5 & 5 \\
\hline $\mathrm{N}$ & 61 & 18 & $\mathrm{Y}$ & $\mathrm{N}$ & $\mathrm{Y}$ & 49 & 27 \\
\hline $\mathrm{N}$ & 92 & 8 & $\mathrm{~N}$ & $\mathrm{~N}$ & $\mathrm{Y}$ & 83 & 110 \\
\hline $\mathrm{N}$ & 64 & 13 & $\mathrm{~N}$ & $\mathrm{~N}$ & $\mathrm{~N}$ & 88 & 35 \\
\hline $\mathrm{Y}$ & 77 & 41 & $\mathrm{Y}$ & $\mathrm{N}$ & $\mathrm{Y}$ & 45 & 35 \\
\hline $\mathrm{Y}$ & 146 & 10 & $\mathrm{Y}$ & $\mathrm{N}$ & $\mathrm{N}$ & 65 & 65 \\
\hline
\end{tabular}

tomography scans. All tomographic series were then processed by 3 Mensio and Osirix MD software with the diameter and angle measurements according to the aortic centerline We decided to use the aortic extension cuff first (ETCF device), followed by balloon inflation and main body deployment (Medtronic Endurant II), as shown in Figure 3.
The general concept was to straighten and stabilize the landing zone area in order to prepare it for the main body deployment. In addition, the cuff material was expected to seal and smooth all irregularities of the neck such as calcifications or circumferential thrombus.

In the second step, the cuff was expanded by a lowpressure aortic balloon for better fixation and sealing. After that, aortography was performed to find any potential leak between the cuff and the aortic wall. If the leak existed, the next dilatation was made. Finally, the main body of the graft was introduced to such a prepared "channel" and deployed exactly on the markers of the cuff. Then another balloon expansion was made. After implantation of the main body the procedure continued with deployment of the iliac extensions. In all 11 cases balloon inflation of the entire endoprosthesis (body and extensions) was made with a Reliant device to smooth all possible irregularities of the inner walls.

\section{Results}

We achieved $100 \%$ technical success during the procedure, resulting in a properly sealed and positioned graft.

In the final angiogram, no type I endoleak was visible in all 11 patients. In the perioperative period we found one 

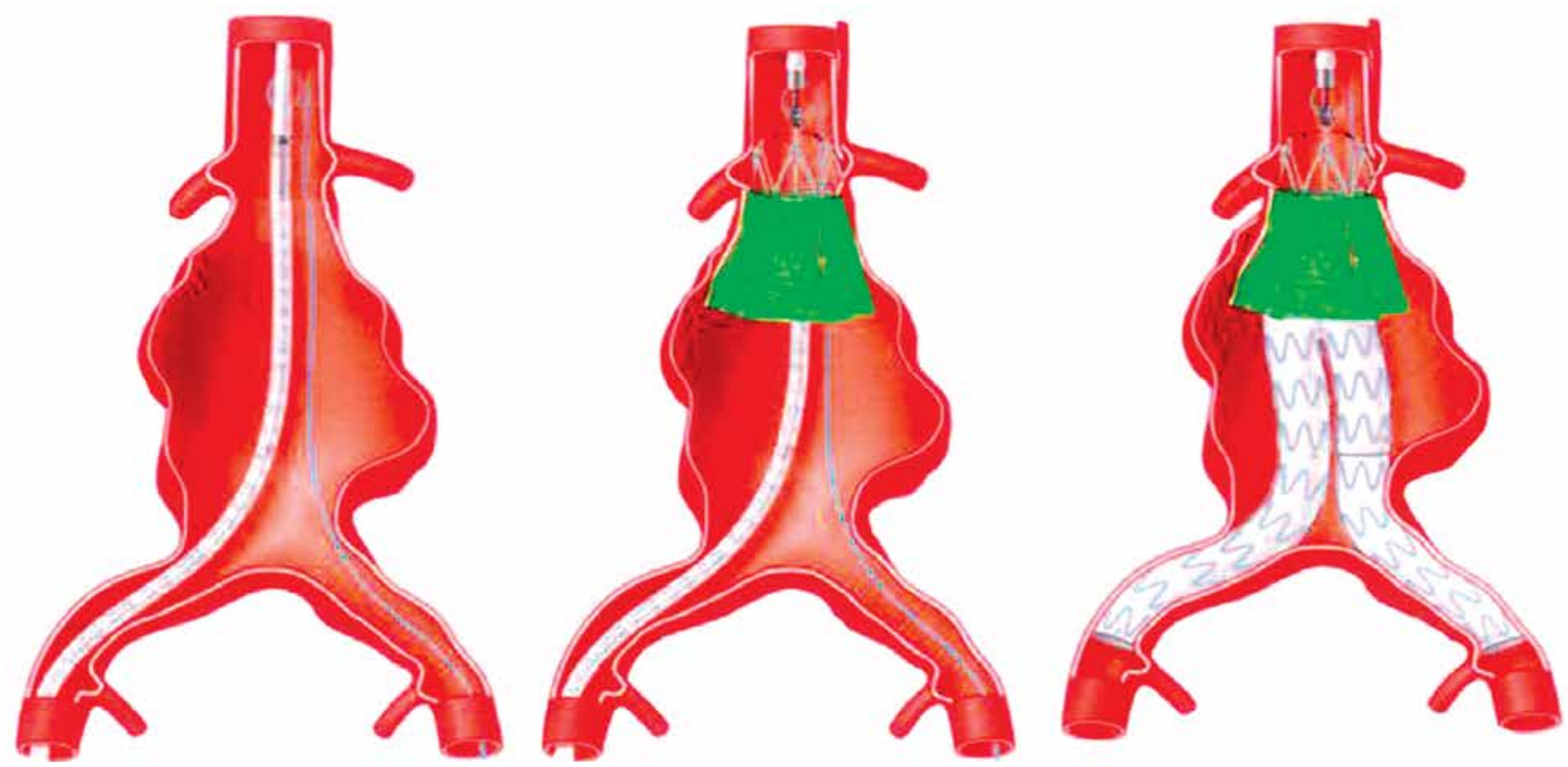

Fig. 3. Procedure concept and steps

type III endoleak resulting from iliac extension disconnection from the main body. That issue was resolved by additional iliac extension deployment, sealing the leak.

Two patients with aneurysm rupture died perioperatively due to a consequence of hypovolemic shock presented on admission to the hospital (Fig. 4).

In 9 patients color duplex ultrasound scans of the aorta were made on the day of hospital discharge and showed no signs of flow outside the graft.

During hospital stay and follow-up we did not observe any thrombosis-related events in all patients. The standard protocol of intravenous heparin infusion was used during the procedure. After hospital discharge patients were taking ASA (aspirin $150 \mathrm{mg}$ daily) together with dalteparin (5000 IU daily for 2 weeks).

\section{Discussion}

In challenging neck anatomy EVAR, fixation and good device sealing are paramount for long-term clinical success [4]. Adequate fixation is defined as deployment of an endoprosthesis that positions the graft under the renal arteries without further device migration. Proper sealing is described as obtaining a tight contact between the surface of the deployed device and aortic wall that eliminates the possibility of blood flow between them after the deployment.

During development of EVAR techniques and devices, the percentage of patients excluded from the procedure due to unfavorable proximal landing zone morphology is systematically decreasing, reaching now the level of 20$30 \%$ of candidates for endovascular repair [7].

In spite of the advantages of EVAR as a less invasive technique, in patients with hostile neck anatomy the longterm outcome is still inferior to open surgery $[6,8,9]$.

During the procedure planning one has to decide between excluding a patient from EVAR or trying to push the boundaries outside the instructions for use of the particular device. As documented in the literature, such approaches are possible, with some additions and modifications of the standard EVAR, that attempt to treat the problematic patients with challenging necks, not eligible for OR or fEVAR.

\section{Endo Wedge Technique (EWT)}

The concept of EWT is to position the graft just below the renal/celiac artery orifice with the balloon inserted partially into the artery. Inflated balloon acts as a wedge preventing graft fabric to close the artery origin. The technique proposed by Minion was initially used with Gore Excluder where balloon fits the flared area of the graft edge [10]. The results described in the literature were good, however such approach was not possible when using popular models with suprarenal fixation as Zenith or Endurant.

\section{Chimney techniques (Ch-EVAR)}

Reported initially by Greenberg in 2003 [11], initial stenting of renal and celiac arteries followed by EVAR allowed the proximal landing zone to be expanded, preserving perfusion

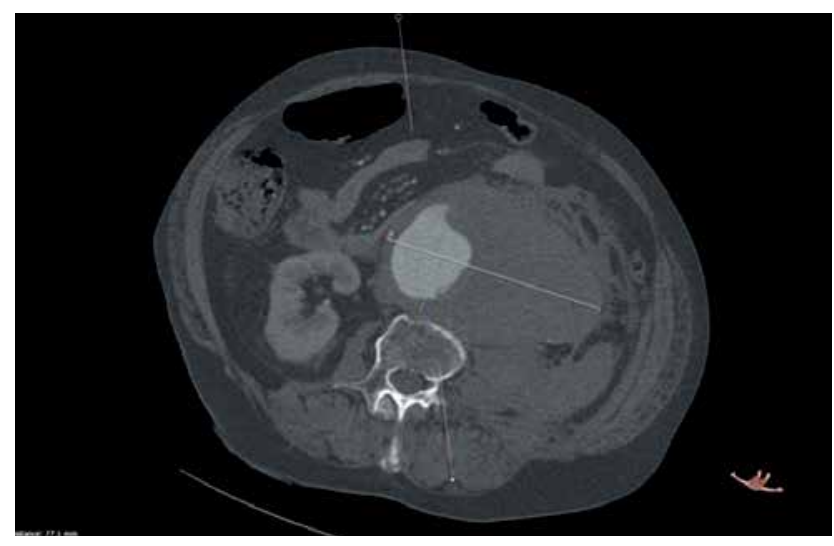

Fig. 4. Example of aneurysm rupture 
of the abdominal organs. Many patient series with the use of visceral chimneys have been described showing relative safety and efficacy in challenging proximal landing zone anatomy. Ch-EVAR was also described as a useful technique in resolving type I endoleak, found during the follow-up period or as a result of a primary unsuccessful EVAR approach. On the other hand, a significant number of post Ch-EVAR renal insufficiency cases and bowel ischemic events have been described, resulting from chimney stents thrombosis or vessel remodeling that led to perfusion impairment.

\section{Uncovered Palmaz Cuff}

The uncovered Palmaz stent implantation was used in unfavorable neck anatomies either as a pre-deployed graft or as a secondary device in order to seal an endoleak found in the control aortogram during the procedure. Some authors have reported good effects and durability of initial bare metal stenting in order to straighten a previously angulated landing zone. Secondary stenting was also described as successful in endoleak sealing by exerting additional radial force that compressed the leak channels.

Critical reviews focused on low efficacy and insufficient long-term durability of the bare metal stenting strategy. Some authors have reported frequent stent repositioning during implantation [12-14].

\section{The use of Endo-Anchors in prevention and treatment of Endoleak type 1}

The use of aortic endostaples after failed endovascular abdominal aortic aneurysm repair was initially described by de Vries in 2011 [15].

The Heli-FX aortic system is composed of an electronically controlled applier with helical EndoAnchors provided in a cassette and a deflectable sheath designed for delivery of the applier to the target location for EndoAnchor implantation. The idea is to mechanically fix the endograft fabric to the aortic wall directly in the endoleak location by the Endo Anchor acting like a screw.

The various ANCHOR study publications report high efficacy and durability of the Heli-Fx system in prevention of the type I endoleak in hostile neck anatomy. The use of Heli-Fx is also effective in dealing with type I endoleak found during follow-up CT scans $[16,17]$. However, an elevated rate of thromboembolic events was reported.

\section{Covered cuff predeployment (kilt) and post-procedure implantation}

In 2009 Minion et al. [4] proposed predeployment of a covered cuff into a challenging neck using the Gore Excluder endoprosthesis which was described as a kilt technique. In 2011 Jimenez and Quinones-Baldrich [12] reported successful kilt implantation in four HNA patients with good long-term results in three of them and one reintervention with Palmaz stent implantation in order to seal type I endoleak.

Setacci et al. [3] reported a review of 72 HNA patients treated with an Endurant II graft. In four cases of endoleak an additional aortic extension was used as secondary sealing of the persistent endoleak.

In a case report Park and Kim [18] described a successful predeployed thoracic stent graft as a kilt prior to bifurcated graft implantation.

In the case of our strategy for patients with hostile neck anatomy, first an aortic extension cuff was pre-deployed below the renal arteries (ETCF). The element was initially oversized in order to straighten the neck in case of angulation higher than $60^{\circ}$.

In addition, a polyester fabric supported externally with nitinol $M$-shaped stents was supposed to provide extra sealing in case of wall irregularities. The possible better sealing and neck straightening in the pre-deployment method is short cuff (length usually $49 \mathrm{~mm}$ ). A short element better fits into irregular, angulated and different shaped necks. When using the main body first, the minimal system length is $124 \mathrm{~mm}$ in the ETBF device and $103 \mathrm{~mm}$ in the ESBF device, which can affect sealing in angulated and irregular areas such as calcifications or thrombi. When we use a cuff as an initial layer acting like a channel to the main body deployed afterwards, the fixation and sealing are much more accurate. By using two oversized elements one in another we also achieve higher radial force, being a derivative of radial forces of the cuff and main body. Higher radial force and better adherence of the kilt fabric to the aortic wall and the main body fabric to the inner surface of the cuff is probably responsible for good sealing and fixation. The preliminary results show that our method is effective when dealing with difficult anatomy outside the device IFU.

Kilt implantation is also a readily available procedure that can be completed using off-the-shelf endovascular equipment and does not require skills unfamiliar to most vascular surgeons.

\section{Conclusions}

Covered cuff predeployment seems to be an alternative to OR and fEVAR for patients with challenging neck anatomy. Preliminary results in 11 patients with HNA using the Endurant aortic cuff and bifurcated grafts confirm that the kilt technique can be applied to a variety of clinical situations with a high degree of technical success. The longterm observation of a larger group of patients is needed to evaluate the efficacy of the proposed method.

\section{Disclosure}

Authors report no conflict of interest.

\section{References}

1. Dillavou ED, Muluk SC, Rhee RY, Tzeng E, Woody JD, Gupta N, Makaroun MS. Does hostile neck anatomy preclude successful endovascular aortic aneurysm repair? J Vasc Surg 2003; 38: 657-663.

2. Tang X, Fu W, Wang Y. Managing difficult aortic necks. A perspective from a Chinese vascular program. Endovascular Today 2014; 83-87.

3. Setacci F, Sirignano P, de Donato G, Chisci E, lacoponi F, Galzerano G, Palasciano G, Cappelli A, Setacci C. AAA with a challenging neck: early outcomes using the Endurant stent - GraftSystem. Eur J Vasc Endovasc Surg 2012; 44: 274-279. 
4. Minion DJ. Neck, seal, and fixation: understanding the differences in these essential components of endovascular AAA repair. Endovascular Today Suppl. 2009.

5. Moll FL, Powell JT, Fraedrich G, Verzini F, Haulon S, Waltham M, van Herwaarden JA, Holt PJ, van Keulen JW, Rantner B, Schlösser FJ, Setacci F, Ricco JB; European Society for Vascular Surgery. Management of abdominal aortic aneurysms clinical practice guidelines of the European Society for Vascular Surgery. Eur J Vasc Endovasc Surg 2011; 41 Suppl 1: S1-S58.

6. Jordan WD Jr, Ouriel K, Mehta M, Varnagy D, Moore WM Jr, Arko FR, Joye J, de Vries JP; Aneurysm Treatment using the Heli-FX Aortic Securement System Global Registry ANCHOR; Aneurysm Treatment using the Heli-FX Aortic Securement System Global Registry ANCHOR. Outcome-based anatomic criteria for defining the hostile aortic neck. J Vasc Surg 2015; 61: 1383-1390.e1.

7. Scali ST, Feezor RJ, Chang CK, Waterman AL, Berceli SA, Huber TS, Beck AW. Critical analysis of results after chimney EVAR raises cause for concern. J Vasc Surg 2014; 60: 865-874.

8. Schwarze ML, Shen Y, Hemmerich J, Dale W. Age-related trends in utilization and outcome of open and endovascular repair for abdominal aortic aneurysm in the United States, 2001-2006. J Vasc Surg 2009; 50: 722-729.

9. Schermerhorn ML, O'Malley AJ, Jhaveri A, Cotterill P, Pomposelli F, Landon BE. Endovascular vs. open repair of abdominal aortic aneurysms in the medicare population. N Engl J Med 2008; 358: 464-474.

10. Minion DJ, Yancey A, Patterson DE, Saha S, Endean ED. The endowedge and kilt techniques to achieve additional juxtarenal seal during deployment of the Gore Excluder endoprosthesis. Ann Vasc Surg 2006; 20: 472-477.
11. Greenberg RK, Clair D, Srivastava S, Bhandari G, Turc A, Hampton J, Popa M, Green R, Ouriel K. Should patients with challenging anatomy be offered endovascular aneurysm repair? J Vasc Surg 2003; 38: 990-996.

12. Jimenez JC, Quinones-Baldrich WJ. Technical modifications for endovascular infrarenal AAA repair for the angulated and dumbbell-shaped neck: the precuff Kilt technique. Ann Vasc Surg 2011; 25: 423-430.

13. Arthurs ZM, Lyden SP, Rajani RR, Eagleton MJ, Clair DG. Long-term outcomes of Palmaz stent placement for intraoperative type la endoleak during endovascular aneurysm repair. Ann Vasc Surg 2011; 25: 120-126.

14. Ahn JH, Kim JY, Jeon YS, Cho SG, Park JK, Lee KJ, Hong KC. Successful treatment of type I endoleak of common iliac artery with balloon expandable stent (Palmaz XL stent) during endovascular aneurysm repair. J Korean Surg Soc 2012; 82: 59-62.

15. de Vries JP, Schrijver AM, Van den Heuvel D, Vos JA. Use of endostaples to secure migrated endografts and proximal cuffs after failed endovascular abdominal aortic aneurysm repair. J Vasc Surg 2011; 54: 1792-1794.

16. Mehta M, Henretta J, Glickman M, Deaton D, Naslund TC, Gray B, McCann R, Jordan W, Fairman R. Outcome of the pivotal study of the Aptus endovascular abdominal aortic aneurysms repair system. J Vasc Surg 2014; 60: 275-285.

17. Jordan WD, Mehta M, Varnagy D, Moore WM, Arko FR, Joye J, Ouriel K, de Vries JP; Aneurysm Treatment using the Heli-FX Aortic Securement System Global Registry (ANCHOR) Workgroup Members. Results of the ANCHOR prospective, multicenter registry of EndoAnchors for type la endoleaks and endograft migration in patients with challenging anatomy. J Vasc Surg 2014; 60: 885-892.

18. Park KH, Kim U. Stent graft using kilt technique for an abdominal aortic aneurysm with a severely angulated neck. Heart Lung Circ 2016; 25: e48-e52. 